\title{
Demand or discretion? The market model applied to science and its core values and institutions
}

\author{
Ylva Hasselberg* \\ Department of Economic History, Uppsala University, Box 513, 75120 Uppsala, Sweden
}

\begin{abstract}
This paper addresses the hypothetical consequences of applying the rationality of the market model to the core activities of science, viz. reading, writing texts, and posing and answering scientific questions. What would happen to science and to our ideas and norms regarding science if we ascribed to the individual scientist the rationality of 'economic man'? The starting point is a discussion of scientific norms and driving forces in the sociology of science. A central conclusion is that science has until now been perceived as being judgment driven, and that scientific judgment historically has been formed in a setting where intersubjectivity has been central. This analysis bridges the gap between classical Mertonian sociology of science and science and technology studies. What then happens to discretionary decision making if we introduce economic rationality into science? Economics tends to treat science from a Mertonian viewpoint, presupposing a value-based rationality, and when economic rationality (the supply/demand mechanism) is introduced, these values are not affected. However, the conclusion of this article is that this would indeed deeply affect scientific rationality. Discretionary decision making would be downplayed, as focus would shift from the text as a means of communicating the result, to the text as a commodity in a market of publication. This would disembed the credibility cycle, and it would alter the character of scientific work and undermine intersubjectivity. Consumption would be disembedded from the context of use and from the norms regarding the use of texts and their value. The knowledge base necessary for intersubjectivity would decrease.
\end{abstract}

KEY WORDS: Discretion - Demand - Scientific rationality - Commodification · Norms · Professional judgment $\cdot$ Academic capitalism $\cdot$ Intersubjectivity

\section{INTRODUCTION}

Research policy in the western world has become more and more central as a policy area. This is an obvious consequence of the perception that universities are institutions with the potential to create growth. Universities, which are in many western countries public institutions, are charged with the mission of creating new knowledge not as an end product but as a foundation for economic growth. As a prelude to this, the development of the public sector of the western world during the last 2 decades has been one of increasing dominance of forms of gover- nance and ideas that emanate from the private sector. A combination of new public management and market solutions has changed the basic idea of what the public sector is and what its purpose is (Exworthy \& Halford 1999). It is important to state that the ultimate source of the new ideas and modes of organization is the neoclassic model for economic behavior, based on the 3 pillars of self interest, competition, and profit. When reorganizing and reforming universities to encourage faculty to act as entrepreneurs, we need to ask ourselves how self interest, competition, and profit will affect the core activities of science: reading, writing, and investigating. 


\section{SCIENTIFIC NORMS AND DISCRETION}

The purpose of this article is to explore the question of what the conceptual economization of the public sector can be expected to bring to the university, and to its particular type of quality assessment, i.e. discretionary decision making based on values of what constitutes good science. What constitutes good science is a matter of values. Since World War II, there has been a common agreement that science should be autonomous, meaning that scientists should themselves exercise control over quality, making judgments concerning the scientific interest and relevance of the question, the soundness of the method, and the validity of results, etc. The norms that should guide the system were that science should be a transparent system of communication, that it should be for the public good, and that it should be disinterested, i.e. not produce a vision of truth that was in the interest of a particular person, group, or organization. Furthermore, it should be based on organized skepticism, meaning that scientists should be critical and skeptical towards one another. This set of norms was introduced in 1942 by the 'father' of sociology of science, Merton (1942/ 1973), and is called 'CUDOS' (communalism, universalism, disinterestedness, organized skepticism.) In spite of recent ideas of Mode 2 science (CUDOS being Mode 1 science), no set of norms as general and comprehensive as CUDOS has evolved to replace it, although Ziman, a sociologist of science, constructed an alternative acronym (Ziman 2000, p. 78-79) that he believed corresponds better to industry-led science, viz. 'PLACE' (proprietary, local, authority, commissioned, expert work).

CUDOS is not, and has never been, anything but norms. The university has never in practice worked according to CUDOS. As a norm system, however, CUDOS has been widely embraced and can be considered the pillar on which the idea of autonomous science rests. Mertonian science stressed the social and institutional character of the norms, meaning that CUDOS, being the foundation of institutions such as the peer-review process, was the foundation of a moral code which set limits to the type of behavior which was socially acceptable. Shapin stressed the deeply ideological character of Mertonian science and its role in forming a notion that science is an exceptional activity performed by exceptional individuals (Shapin 2009 p. 249, 312-313). In Shapin's version, CUDOS rather has the role of shielding science from external interests, or claiming a difference between 'pure' university science and 'dirty' indus- trial science, than of affecting the actions and beliefs of scientists and scholars. It is the ideology of autonomous science, and as for all ideologies, it should be regarded with suspicion. Questioning this ideology leads, in Shapin's case, to the claim that there is no fundamental difference between science carried out for profit and science carried out as a result of a will to expand existing knowledge (Shapin 2009). Accepting the ideological character of CUDOS, this is not an innocent claim. It too is fundamentally ideological, on the one hand possibly erasing the constructed differences between university science and science performed for profit and on the other hand possibly having the effect of letting profitdriven science access Mertonian ideology and use it as a 'trademark'.

In this article, I make a different claim regarding the role of CUDOS in science. My claim is that scientific norms do not solely have the property of being a tool in boundary work and battles for legitimacy, what we could call the external reproduction of science. I claim that CUDOS, or any other set of scientific norms, plays a central role in the reproduction of science as professional work and scientists/scholars as professionals. The crucial link in my chain of argument is discretion, or discretionary decision making. Discretionary decision making is something that scientists have in common with other professional groups (cf. Hawkins 2001). Professionals are historically characterized by a certain type of decision making, based on professional judgment. Judgment is dependent on the knowledge that is particular to a profession, and that separates it from other professions. The exercise of discretion is individual.

The inherent meaning of discretion is that a certain space is left for decisions that are value-based. It is a question of basing decisions on what is perceived to be good, correct, or even beautiful. A number of adjectives can be used to capture this property or lack of property of a scientific question/theory/method/result. Is it a fruitful question? Is the solution to the problem elegant or clumsy? Is the author of a paper a brilliant analyst or too speculative? The process of discerning ('separating wheat from chaff') and forming a judgment is value-based, and it is also subjective, in that the mental capacities and knowledge embodied in the subject are the basis of forming a judgment. Scientific norms are instrumental in this process.

Scientific judgment is thus qualitative, combining context-dependent knowledge and valuation. It is also based on a combination of 2 types of knowledge. Marglin (2008, p. 130-131) distinguished between 'algorithmic' and 'experiential' knowledge. 
Algorithmic knowledge is basically deduction, and is founded on rational use of our mental faculties. It is also theoretical. It grows incrementally, in a process where all logical possibilities are explored and nothing is left to the imagination. Algorithmic knowledge lacks body, and it is impersonal and objective. It is the same everywhere and it is also (theoretically) accessible to everyone on the same conditions. This type of knowledge is accessed through formal schooling or logical reasoning.

Experiential knowledge 'runs the gamut from the authority of recognized masters (and mistresses) to one's own intuition' (Marglin 2008, p. 131). It is affected by habits, conventions, culture, and power. It is the type of knowledge founded on experience and history, and it has a social context. It is far from impersonal and objective. Experience is linked to a certain social and historical setting. Experiential knowledge is formed in relation to this context and with a determined purpose. It is reproduced through social relations, often through imitation and example (Marglin 2008, p. 131-133).

Although the legitimacy of modern science rests on the claim that algorithmic knowledge is central and experiential knowledge more peripheral, both exist as bases of scientific work. We are totally dependent on experiential knowledge when making new discoveries. There is no way of accessing new discoveries through algorithmic knowledge; it takes creativity and/or serendipity, not logic. Marglin (2008, p. 131) wrote: 'To discover or to create through algorithmic knowledge would be like the proverbial monkey typing Shakespeare: he might some day do it, but we would be hard-pressed to find the wheat among the chaff.' We are thus, if we want to keep on expanding existing knowledge, dependent on scientists and scholars basing their decisions on discretion, which in turn rests on a combination of scientific norms and algorithmic as well as experiential knowledge.

\section{SCIENTIFIC RATIONALITY}

What is the driving force of scientific rationality in the Mertonian concept of science? This is a central question to this article. If we want to explore the potential effects of the introduction of economic rationality in science, we need to understand what the alternative is. We also need to assess social and economic aspects of Mertonian science. In Merton's view, scientists were driven by a thirst for recognition. Recognition is - as one can understand if one undertakes a conceptual analysis - a social value.
Recognition depends on the work being heeded and recognized as important by fellow scientists, one's peers. Recognition could then be traded against economic benefits that were to be distributed according to a strictly meritocratic principle. One of the central research areas of Mertonian sociology of science was precisely the reward system of science and the consequences of its construction: the Matthew effect, the occurrence of multiple discoveries, and priority conflicts. Such issues are all related to the fundamental issue of how the reward system functions and how this in turn affects the rationality and actions of scientists (Merton 1957/1973, 1960/1973, 1968/1973a, 1968/1973b).

When did economic rationality enter sociology of science? Knorr-Cetina (1982) rightly remarked that it was there from the beginning, since Mertonian science is fundamentally competitive. Still, KnorrCetina also noticed that the economic aspect of scientific rationality as perceived by sociology of science has tended to grow stronger over time. Hagstrom (1965) placed scientific rationality within an economy based on gift giving, i.e. not within a market economy. The logic of the gift, originally stemming from the writings of anthropologist Mauss (1925/2002), presupposes a strongly reproductive and integrative type of economy, where the social bonds are in focus. The gift is a medium with which the ties between actors are upheld, through the overarching duties of giving, accepting, and reciprocating a gift. The gift economy has a strong normative stance, and the functionalist ideas of Mauss are very much compatible with Mertonian sociology of science. However, the real breakthrough for economic models of scientific rationality, according to Knorr-Cetina (1982), comes with Bourdieu's introduction of credit and symbolic capital as driving forces for individual scientists. When science becomes a matter of accumulating symbolic capital in order to compete and dominate, then our concepts firmly place this agent within a capitalist system.

In the 1980s, Mertonian functionalist ideas of science were challenged by constructivism, questioning the meaning and importance of norms in relation to social action in structuring scientific practice. This also meant a re-writing of the fundamental driving forces behind the actions of the individual. Latour \& Woolgar (1979/1986) introduced the idea of a 'credibility cycle' around which the rationality of scientists is centered. In doing this, they introduced the idea that scientists are investors searching for credibility, rather than recognition. The cycle is a cycle of conversion, converting money, data, prestige, papers, 
etc., into credibility. The cyclical character of this process also means that the credibility gained is constantly and repeatedly reinvested.

Hessels (2008) recently pointed out that the traditionally conceived contradiction between Mertonian recognition and constructivist credibility is bridged by common features, above all the importance of norms concerning what good science is. What is reliability? What is a valid result? I would like to complicate this argument by shifting the focus slightly, from norms to discretionary judgment, seen not only as something that is linked to and dependent on norms, but as an activity that is necessary to reproduce the idea of what good or even acceptable science is. Professional judgment is central to answering the question of what good work actually is, and this in turn is central to the identity of the professional as a craftsman, as somebody who has spent time and energy to learn to master his/her tasks; to do it right. As Sennett (2008, p. 144) stated, 'the craftsman...represents in each of us the desire to do something well, concretely, for its own sake.' Professional judgment is the core fundament in a value-system which sees quality as a goal in itself, not as an instrument in achieving other goals, such as utility or efficiency.

A good example of the context-dependent and complex process of forming scientific judgment can be found in a recent article by Michael et al. (2007). The authors examined the controversy regarding the so-called Lumelsky protocol in stem cell research. They reach the conclusion that the scientists 'who jumped on the Lumelsky bandwagon' can be rehabilitated, i.e. regain the trust and respect of their peers, as a consequence of the recognized chronic uncertainty in the stem cell field. This is an excellent example of how discretionary decision making takes the whole of the context into account and results in a nuanced and very specific conclusion as to how trust and blame are produced and distributed. One needs to be an experienced stem cell researcher to be able to produce such an informed judgment.

The stated example points to another common characteristic of Mertonian and social constructivist ideas on the driving forces of science. Recognition and credibility are both produced in a social context and place great emphasis on trust and reputation within the scientific community. Discretionary decision making is dependent on a shared set of norms, and its task is to reproduce the norms as well as the trust and the social and economic position of the members of the community themselves. The relationships within the community are thus central to scientific judgment.
This also has consequences for the meaning of knowledge in an academic context. Knowledge is relational. Callon (1994, p. 411) stated: 'In effect, the main result of scientific activity is not to produce information but to reconfigure heterogeneous networks'. In Callon's rationale, the relational and the contextual aspects of scientific knowledge present an argument against the possibility of commodifying it. Information can be commodified, whereas knowledge cannot.

In summary, I like Hessels' (2008) view that it is possible and perhaps even desirable to bridge the gap between Mertonian and social constructivist ideas on the driving forces behind scientific action, in order to create a few denominators of scientific rationality. These are (1) embeddedness of the credibility cycle in scientific norms expressed in discretionary decision making, (2) the relational character of scientific knowledge, and (3) intersubjectivity as a collective producer of trust within the scientific community. These are all characteristics of scientific rationality, and can be used as a starting point for discussing the meaning of economic rationality in science.

Hereafter, I refer to scientific rationality as judgment driven. My conclusion from this exploration of professional judgment and the role of norms in scientific rationality is that the problem with Mertonian norms is not so much that they cannot be used to discriminate between different scientific practices and rationalities, but more that they cannot be used to discriminate between how profit-driven and judgment-driven scientists present themselves socially. Judgment-driven and profit-driven scientists may well differ in their approach to scientific endeavor. The question is what the differences really are and what their consequences are. This question is addressed below.

\section{SCIENCE AS A COMMODITY AND THE COMMERCIALIZATION OF THE UNIVERSITY}

What could an economization of science possibly mean? Is the economization of science necessarily the same thing as the commercialization of the university or the marketization of higher education? It is my impression as an economic historian that there is a lot of confusion in the ongoing discussion regarding the empirical focus (are we talking about the university, science, higher education, or the scientist) of change as well as the nature of the change (e.g. marketization, managementization, commercialization). It seems to me that although there is interrelatedness between these concepts, it would be wise to keep 
them separate, for analytical reasons. A marketization of the university could occur without very much commercialization going on. New Public Management as a reform movement occurring in the public sector in the entire western world has introduced 'fake' markets in the public sector without there being either buyers or sellers; in fact, with little commerce going on at all (see Rombach 1997). Commercialization, on the other hand, can possibly go on without affecting the internal economic logic of science: its rationality, norms, and mode of organization. This is a common argument from those who are convinced of the necessity of turning scientific results into marketable products (see Greenberg 2007).

In an unmistakably Hegelian and rhetorically very efficient style, Mirowski \& Sent (2008) divided the ongoing research on the commercialization of science into 3 categories. The first 2 categories are defined primarily by their ideological stance: one is strongly opposed to commercialization and the other supports it. 'Opposed to' commercialisation are the 'motley ranks of Cassandras,' idealistic Mertonians who believe in the golden age of scientific purity. 'For' commercialization are 'the massed phalanx of neoclassical economists, science policy specialists, and their bureaucratic allies,' according to which 'the economy must constitute the ultimate arbiter of scientific success in this more rational regime of organization' (Mirowski \& Sent 2008, p. 635-636). The third category is the type of research that they as science and technology studies (STS) researchers represent, which is historical research aimed at explaining the development. Mirowski \& Sent (2008) adopt a more structuralist perspective than what they state as normal among the often micro-level focused STS research. The commercialization of science in the US can only be understood in the context of how the industry and the state have interacted with the university and how resource flows have forced universities to adapt. Money talks: it affects scientific practices, and a critical assessment of how this is done is the task of STS. Their historical argument is fully convincing to an economic historian. What they come up with is a periodization and something similar to scientific 'regimes' embedded in 3 wholly different politicoeconomic contexts. The present regime, the 'globalized privatization regime,' is characterized by a withdrawal of state money at the same time as private enterprise has 'outsourced' research and development to the university and closed down its own research facilities. A similar, systematic, approach has been launched by Slaughter and colleagues (Slaughter \& Leslie 1997, Slaughter \& Rhoades 2004). Slaughter \&
Leslie (1997, p. 8-9) explored the current regime and christened it 'academic capitalism,' by which they mean 'institutional and professorial market or marketlike efforts to secure external moneys... Capitalism... is defined as an economic system in which allocation decisions are driven by market forces.' Slaughter \& Leslie (1997) are thus clear in what they consider the change to consist of: the introduction of the market mechanism into the university as an institution.

I accept as central the conclusion that there is a link between the development of capitalism in late modernity and the condition of science in the same period. The concept of a globalized privatization regime as a blanket term for the ongoing processes is useful. However, I am not certain that there is a 1-way causal link between an 'economic base' and an 'ideological superstructure' so that a unanimous recommendation would be to go out and study the effects of changes in the economic base. Rather, I think that placing 'academic capitalism' in its historical context will have to include the realization that the 'market forces' are not actual empirical phenomena (unlike patents or tech transfer offices), but aspects of a theoretical model. There are and have always been markets (as countables: 1 hay market, 2 regional markets), but the market model, according to which the economy becomes subsumed under market 'laws,' is a child of the 19th century. The market model conceptually disembeds the market from the rest of society, i.e. its morals and its social relationships, as was demonstrated by Polanyi (1944/ 2001 ) in his seminal work on the change of 19th century economic thought. It also actually frees the idea of market economy from production and from economic action. The goal of economic rationality is accumulation itself, expressed as money-commodity-money, instead of the pre-capitalist commodity-money-commodity. A modern concept of economy, in opposition to a preindustrial concept of economy, does not include economic activities that have no relationship to the market.

The market model, just like CUDOS, carries a normative stance. Unlike CUDOS, however, it does not admit it. The market model presumes a specific rationality linked to the price mechanism, its focal point. It presumes; it does not prescribe. However, the hegemonic character of the market model makes it very difficult for the individual actor to stray from economic rationality. The grandeur of Weber's (1904-1905/2001) analysis of market rationality lies precisely in his ability to extrapolate from existing facts and reach the conclusion that economic rationality is becoming embedded in an economic system. 
The capitalist system, at the time when Weber wrote, was gaining momentum, making conscious individual rationality superfluous. The market model constitutes part of this process, and can be seen as performative in relation to economic action, creating the type of economic behavior it purports to describe.

Mirowski (2011) recently summarized many years of research into the relationship between economics and science. His central claim, which also constitutes an analysis of the nature of the relationship between knowledge and the market model in the present science regime, is that the pervading metaphor for this relationship is that of the market as an information processor, and that this has resulted from the actions of proponents of mainstream economics and neoliberalism (Mirowski 2011, p. 44). This statement actually comments on a number of aspects of the development of the science/economy relationship. It points to the importance of the development of information technology for the development and reception of economics as a commentator of science, and to the market model's invasion of information technology. But it can also be analyzed as a statement that regards the overall introduction of the market model as a general lens through which all human action and all decision-making processes should be seen, even within science. What then would this mean for the rationality of the scientist? Mirowski, who does not specialize in the analysis of individual actors, leaves this question aside, instead concentrating on a number of areas crucial to the current regime, such as intellectual property and the consequences of the ties between science and big pharma. He merely hints at the problem, commenting on the logical fallacy that arises from the fact that economists as scientists assume the scientist to be a neoclassical agent, with 'fixed, well-behaved preferences, knowledge modeled as a commodity, fixed cognitive and epistemic abilities of the agent, and the ability to survey and question the aptness and logic of the model describing his predicament' (Mirowski 2011, p. 335), while it would not occur to them to regard themselves in this mirror. Although this is certainly an interesting logical problem, what I would like to know is what would happen to the rationality of science if scientists were to act as neoclassical agents.

Returning to the question of the various concepts that can be used to analyze the development of the present science regime, and the various levels of analysis that are possible, this article focuses (1) on the individual scientist, and not on the university as an organization, (2) on commodification of science, creating rational actors in a market for scientific goods, and not for example on marketization of the university as an organization or commercialization of higher education. Commodification means (1) that the relationships that surround a commodity are transformed into market relationships and (2) that exchange value or market value will take priority to all other kinds of value. Work that does not contribute to market value is meaningless. Knowledge that cannot be transformed into a marketable product with a market value is also meaningless (Ball 2004).

The aim of this article is thus to investigate the hypothetical consequences of applying the market model to science, replacing 'the market as an information processor' for scientific judgment. How would scientists act were they to be rational actors in a market for scientific commodities? This means freeing market logic from money and inserting recognition/ credibility in its stead. Is it only to achieve recognition (the currency of science) that we publish? Or is the goal to reproduce and produce science itself? If the ultimate goal of science can be stated as recognition/credibility, subsuming texts, relationships, knowledge, under this logic, then the pattern of rationality can be described as recognition-articlerecognition in 'science as a market.' In 'pre-market science,' the pattern can be described as articlerecognition-article. Knowledge has value independent of its ability to create accumulation of credibility/recognition, and scientists are judgment-driven actors in a social context where most other actors are also judgment driven.

\section{ECONOMISTS ON SCIENTIFIC RATIONALITY}

A central conclusion of Mirowski (2011) is that the ideology that underpins the present science regime has been formed largely by economists, with the market as information processor as the model. I think it is proper to reflect on this as a parallel to the historical process pictured by Polanyi (1944/2001). Disembedding the market from its social context ('freeing the price mechanism') had grave consequences for society, and eventually led to the spontaneous evolution of mechanisms that re-embedded the market in society through regulation. Translating this process to the present development of higher education, we have, during the last few decades, seen the beginning of the reformulation of the system of higher education on the pattern of the market model. The consequences still remain to be seen. What can substituting the market as a processor of information for judgment-driven rationality possibly lead to? This we can- 
not know at present, but what we can do is to scrutinize the ideology that underpins the process, much as Polanyi (1944/2001) did, analyzing the writings of classical economists and the effects their ideas had on political debate and subsequent institutional change.

What do the economists have to say about the production of knowledge? What type of rationality do they propose? The classical analysis of this area was undertaken by Arrow (1962). The central problem that he worked on and tried to solve was how enough new knowledge can be produced in society. He analyzed the driving forces of knowledge production and reached the conclusion that science should be seen, and consequently organized, as a public good, as the inherent character of information as a commodity hinders it from being exploited efficiently by any one owner or interested party. 'Perfect competition' will not be able to achieve optimality in resource allocation, as it will not be rational to invest in information when the production of information will not primarily benefit the investor. He reached the conclusion that science should be financed and organized by the state, and furthermore, he advocated for 'the importance of non-pecuniary incentives, both on the part of the researchers, and on the part of the private individuals and governments, who have supported research organizations and universities' (Arrow 1962, p. 623). The growth of science is dependent on it being kept separate from the market. Arrow trusts the driving forces of individual scientists to be something quite different from the driving forces of, say, the Chief Executive Officer of Microsoft or General Motors. A modernized version of this message can be found in Dasgupta \& David (1994). Although these authors focused on a partly different problem, namely not how knowledge is produced in the best way, but how one achieves 'a maximal flow of economic rent from the existing stock of scientific knowledge by commercially exploiting its potential for technological implementations' (p. 518) they rest firmly on the same basic assumption: 'the institutions and social norms governing the conduct of open science....are functionally quite well suited to the goal of maximising the longrun growth of the stock of scientific knowledge...' (Dasgupta \& David 1994, p. 518). The authors, adopting a quite naive version of the linear model, assume that the diffusion of knowledge (i.e. commercialization) can be more efficient but still warn against 'destabilizing and potentially damaging experiments' with the institutional machinery of science. The view of the economists seems to stress the idealism of open science, revealing a rock-steady belief in the ability of its core institutions to withstand any claims of change from society. Their view is shared by many who gladly promote commercialization of both science and teaching. As Greenberg (2007, p. 101-126) demonstrated, even the most devotedly capitalist of university presidents will embrace the values of open science, especially when charged with breaches of code of conduct.

A close-up study of the writings of economists on scientific rationality reveals some peculiarities of this particular version of Mertonian rationality. Diamond (1988) explicitly referred to Merton as the starting point of his analysis of 'science as a rational enterprise,' as did Stephan (1996) in an attempt to formulate the basis of an economics of science. The Mertonian ideal-typical scientist, striving for recognition and trying to establish priority in order to achieve it, is saddled by Diamond with a particular type of utility maximization, which relies on a search for the most elegant theory or the theory with the biggest scope. The scientist maximizes utility through this activity, and can thus be considered rational. In order to make this claim, Diamond (1988, p. 156) assumed that 'there must be objective criteria for judging theories.' In making this assumption, discretionary decision making is effectively robbed of a role in the process of creating new knowledge. Logically, it then becomes quite impossible for scientists to be judgment driven, since judgment is not necessary. Diamond's (1988, p. 150) rational scientist is value driven, but not judgment driven. Value is not a question of norms; it is a consequence of the assumed objective properties of a theory.

Diamond (1988, p. 152) discussed 'stylized facts,' which seems to refer to 'facts' that are not located in a historical setting. The social setting, as Hands (1996) aptly formulated it, amounts to 'summing the individual agents,' nothing more. The resulting model of rationality fuses a perverted Mertonian concept of science that is value driven, but stripped of all social and subjective aspects, and of its historical setting with an idea of science as an economic enterprise, a specific type of production (Stephan 1996, p. 1229). It is seemingly easy to relocate Mertonian rationality to a market setting, using a totally different set of analytic concepts. Priority becomes a question of property rights. Production of science becomes a question of the number of publications, i.e. the output in terms of countables (Diamond 1996). Seeing science as economic enterprise then allows for questions like how productivity can be raised, how the reward structures of science can be perfected in order to encourage higher productivity, and how the element of risk in- 
volved in the search for new knowledge can be handled so as to remove impediments to the production of new knowledge. Overall, these questions address the larger question of efficiency. If we assume that scientists are rational agents maximizing utility in their search for the objectively most elegant theory, and then producing papers for the market of ideas, how can we increase efficiency in this enterprise? A question such as this inevitably leads to issues that regard reward structures, not the least of which are financial rewards (Hanson 1995, Diamond 1996, Stephan 1996, Stephan \& Everhart 1998). When the issue of how scientists are rewarded for their efficient production of new knowledge is raised, the peculiar thing is that the fact that science can be improved through the introduction of an efficient reward structure (implying that scientists are drawn to the highest financial rewards and that they compete for them on a market for scientific labor) is not assumed to affect the inner logic of science. The Mertonian inner core of scientific work is left untouched by the assumption that scientists are also, at the same time, rational market actors. I do not hesitate to call this version of scientific rationality paradoxical.

The Mertonian character of the economists' view can in fact be seen as a loop, the direction of influence being less than clear. The history and sociology of science contains some very influential borrowings from the field of economics, although no influences have come directly from the neoclassical model, which is too far removed from issues regarding individual action to intervene with the sociology of science. Instead, the borrowings have been indirect. Merton fell back on puritan values as an important source of explanation for the rise of scientific rationality. What made the scientist different from other people was that the scientist was ready to renounce immediate rewards in order to reach a more distant goal: long-term accumulation of knowledge. Frugality, self-control, and the ability to postpone or totally relinquish immediate material gain were the hallmarks of the scientist (Merton 1935/1970, 1938/ 1973). Merton attributed the scientist with the same characteristics as the ideal-typical capitalist analyzed by Weber (1904-1905/2001). Rationalism is an important ingredient in both concepts, the ability to act according to a means-end rationality being crucial to function as a scientist or capitalist. Weber's idea of the birth of the rational capitalist in turn became the sole most important historical foundation of the empirical existence of 'economic man.' Weber furnished the neoclassical model with a sociological foundation for its most fundamental premises. The theory of the protestant ethic giving birth to the spirit of capitalism also turned the interest from the, admittedly not very frequently asked, question of whether there really was such a thing as a spirit of capitalism to the question of how its (assumed) existence could be explained. There is thus an evident conceptual link between the concept of the rational economic actor and the rational scientist.

Critics of the economic view of science, including Callon (1994), say that the core problem of the economic view is not that it sees the scientist as a rational market actor, but that it sees knowledge as a commodity, which, according to Callon, it is not. Furthermore, science does not become a public good as a result of any intrinsic quality which hinders it from being appropriated by diverse interests. Callon rejects the general and abstract view of scientific knowledge held by the economists in favor of a contextualized, relational, and situation-bound view of it. If Callon is right, science (or information) is perhaps not a commodity, but neither does it have any inherent protection from the abuse by either scientists themselves or other actors.

How does institutional change occur and what can be done to affect it? The process of disembedding the market mechanism from science and giving it priority is not only a matter of the economic base, but also of how we, in our social relationships, conceptualize science as an activity and ourselves as scientists. The Swedish business scientist Rombach (2005) pointed out that the economization of the public sector also has a conceptual dimension; it is a matter of speaking economics, just like we speak English or Swedish.

What this article is meant to achieve is an exploration into the possible consequences of introducing a number of fundamental concepts fetched from the economic field into the field of science. The method is deductive; what I want to know is what happens to our norms and ideas about the university if we choose to 'speak economics.' If we talk about science as a type of market-driven economy for scientific commodities, instead of a judgment-driven activity which aims at creating new knowledge, what does this do to the identity of the scholar or scientist, or to norms regarding science?

\section{SELF INTEREST AND COMPETITION}

It should be pointed out that the following analysis does not take the state of the art in the discipline of economics as a starting point. Concepts such as bounded rationality, asymmetric information, or 
rational expectations, that are central to mainstream economics and have played a role in the evolution of the idea that the market is primarily a processor of information, notwithstanding their lack of suitability for exploring what knowledge is (Mirowski 2009), will not be given further attention. The reasons for not fitting the ideal-typical scientist into a frame constructed on the basis of these concepts and ideas are 2-fold. Firstly, my aim in the following is to give concretion to the overall idea of science as a form of economic action. This means that I aim at undertaking the analysis on a level which will make the actions of the individual in a particular social context visible, and permit the reader to draw a parallel between his/her own empirical observations and my text. Therefore, the concepts applied are not the highly abstract ones of mainstream economics, but rather the ones (e.g. profit, competition, products and firm) which can be found in a daily paper aimed at the general public, and that also surface in present public discussions of how universities should be organized and funded. Some of these concepts are rooted in business studies as an academic discipline rather than economics. Secondly, another reason for not fitting the scientist into the framework of mainstream economics is that this framework has as one of its main characteristics the combination of the aforementioned high level of abstraction (leaving the social and historical 'empirical' context aside) with a strong inner coherence and a totalistic claim for relevance. The neoclassical model is in some instances more of a worldview than a theory, and applying it to science makes perfect sense, holding this worldview. The rationality and inner coherence of the model hides the conflicts as well as the dynamics of the development of science today, and is therefore not suitable for the purpose.

Mainstream economics is founded on the claim that the economic actions of individuals are driven by the universal goal of maximizing their own economic gain; they act out of self interest. In doing this, they compete with other individuals for the same economic gain. The original empirical support for this idea was the pre-industrial merchant engaging in what is in Marxist terminology called 'original accumulation' (Braudel 1982). As capitalism becomes organized, this behavior is transferred to aggregates of individuals, e.g. economic partnerships, firms, large enterprises. 'Economic man' is a purely theoretical construction. The original idea of a rational, profit-maximizing individual is to a great extent untouched by time. Moreover, it is an idea that has resisted all attempts to reform or develop neoclassic economic theory, for example by neoinstitutionalists. If we take North's (1990) variant of neoinstitutionalism as an example, which constitutes one of the more well-known attempts to understand how the economy works in a social and historical context, it leaves the fundamental idea of a profit-maximizing individual engaged in competition out of its ambition to complement and contextualize neoclassic economic theory. Institutional theory thus becomes a helping hand to neoclassicism. The rational individual is a necessary theoretical prerequisite to neoclassicism, without which there would be no theoretical foundation for the belief in a functioning price mechanism whatsoever. Individuals (consumers as well as producers) have to make choices that are economically rational, in a very narrow meaning, in order for the price mechanism to be a valid construction. There are of course various adjustments and limitations of the theoretical claim of economic rationality. Rationality is limited by lack of complete information. Rationality can in certain situations be overtaken by values, loyalties, or habits that cause the individual to make decisions that are not rational. In fact, as has been pointed out, rational choice presupposes the existence of non-rational behavior, and tends to contribute greatly to the imagined gap that separates society from community (Douglas 1986). Still, in the neoclassic concept of economy, the bottom line is always 'economic man.'

What happens to the role of the scientist/scholar when we look at him/her as a subspecies of 'economic man?' For the sake of clarity, I think it is necessary to make a distinction here between the scientist as a producer/investor and the scientist as a consumer. This means that scientists can have different relationships with the market: they can be sellers or buyers. As producers of scientific knowledge, scientists sell this knowledge on a market. As buyers of the same knowledge (that is the raw material on which academic production is based), they acquire it on a market. The market is another fundamental part of the model. Without a functioning market, there is no functioning price mechanism.

\section{THE SCIENTIST AS A PRODUCER}

The scientist as a producer produces knowledge, which he/she sells on a market. The concrete products consist of scientific papers, books, or possibly public speeches at conferences. There is a market for such commodities, and a separate market for future goods (we can think of it as a market for options on 
knowledge), namely a market for scientific ideas that are in need of funding to be turned into knowledge. These options are accompanied by assessments of the previous productivity of the scientist, in the form of a publication record. Therefore, the 2 markets are to some extent interrelated. There are also 2 forms of valid currency on the market: economic and cultural capital. Economic capital equals funding in one form or another. Cultural capital equals recognition or status. It can be traded for economic capital, and vice versa.

According to the market model, the self interest of the scientist leads him to sell his knowledge at the highest possible price. This means that he/she wants to exchange as little knowledge as possible for as much cultural and economic capital as possible. This is rational, according to the fundamental concepts of the model. This means that demand determines what knowledge gets produced. Demand replaces discretion as an ulterior motive for producing knowledge. Knowledge that is not in demand will not be produced. It also means that there is no driving force towards procuring as much knowledge as possible. Producing too much knowledge will increase the supply and as a consequence lower the price, if demand is held constant. Neither is it consistent with the model to produce knowledge of higher quality than what is being paid for. The ultimate deal is to produce the exact quality and amount that is paid for, at the highest possible price per unit. Consider the following example, from an area within academic life where market mechanisms are really implemented in concrete. If the market for publications pays better for articles than for books, it is not rational to produce books. If the market for articles pays better for 2 short articles than for 1 longer and more thorough specimen, it is rational to divide the knowledge to be communicated into smaller pieces, notwithstanding the consequences for the knowledge itself. Dividing research results into smaller parcels and publishing them separately in order to produce more merits is called 'salami-publishing' and is considered an acceptable strategy in some parts of the academy (Gollogly \& Momen 2006). The scientist on the market does not care for knowledge in itself. Values as well as emotions are external to the market model, and if they come into the picture they possibly create disturbances or market imperfections.

There are of course some complications to take into consideration here. I have postulated that it is clear to the buyers and sellers of knowledge what the exact nature of knowledge is, and that they can agree on this, as well as on how to measure quality in knowl- edge. In practice this is of course a sticky problem, where preferences as well as access to information differ. This fact is one of the fundamental insights of sociology of science. However, universal methods of measuring the quality are evolving at least in the field of article publishing, where the journal impact factor (JIP) has become a standardized way of transforming demand, measured as citations, into a quality assessment.

It is evident that bibliometrics play a cardinal role making possible the transformation of the scientist into a producer of articles. The problems that arise as a consequence have previously been discussed by Fuller (2000, p. 93), who noted: "The closest Price and Merton got to specifying the "ends of science" was the indefinite accumulation of highly cited scientific articles. ...We have yet to take the Smithian turn in our understanding of science, whereby progress would be judged more by the quality of its people than the quantity of its papers.' Bibliometrics contribute to a notion of science as essentially centered on its end products, assessing the quality of the knowledge through the quantity of the products and the quantity of the demand for these products.

As scientists produce for a market, they also compete. What then is competition, in the market model? How can the concept be used in a relevant way in an academic context? For a producer of scientific knowledge, competition can be aimed at many things. There will be competition for tenure, competition for funding, and perhaps also competition for claiming an important discovery. All these forms of competition are normal in a system built on meritocratic principles. The scientist with the best merits gets the job - at least that is how it should work in theory. In practice, there are many instances where meritocratic principles are set aside, often as a result of differences in scientific taste. If we disregard practice for a while, it becomes clear that competition in the meritocratic system means competing with your merits (their quality as well as quantity) for a specific benefit (e.g. a prize, a position, research funding). Is that not exactly what takes place in a market? However, the difference is that the basic mechanism behind the meritocratic principles of the academy is discretion, not demand. What happens if we substitute demand for discretion?

The market model presupposes that the price is the fundamental regulator of the economy, creating equilibrium between demand and supply. This means that demand must be allowed to influence supply, and vice versa. If we start with the supply side, there is a built-in propensity for suppliers to try 
to increase the demand for their product. This is something that in the industrial society has led to an utter refinement of activities like marketing. If you want to sell your product, somebody must want to buy it. If scientists are on the market, they must market their products. The existence of a new piece of knowledge in itself is not enough. Moreover, they must do this with the ulterior goal of selling, not of producing knowledge, and of selling more knowledge than do their colleagues. Conferences are a perfect forum for doing this. Presentations of papers can easily be turned into sales presentations, with the purpose not of informing of new results or of improving one's argument, but of convincing the buyers that the product is good.

There are various strategies of competition in a market. One is aggressive marketing, as in the example above. Another is to compete with price, something that works best if the products are fairly standardized. Translating this to the academic system, it could mean publishing a lot of texts of mediocre quality which do not create too much new knowledge, and are not too difficult to assess in terms of quality. It means that you only procure a limited amount of new knowledge, and a type of knowledge that will be acceptable to many consumers, whether they are journals, fellow scientists, or the public in general. What you produce are black Model T-Fords in publication form. Your aim is to produce them cheaply, ruling out extensive reading of literature, difficult source materials, or time-consuming methods. This means that real innovation, e.g. production of knowledge that runs counter to the existing stock of knowledge, does not come into the picture. To market such knowledge is a risky affair. Buyers may not know what to do with this knowledge, and it is quite likely difficult to integrate it into the existing production system (buyers often consume knowledge directly but they also wish to integrate it into their own production).

Of course there are also other strategies. One very risky strategy is to indeed aim at producing something which is of very high quality and that comes with a corresponding price tag. Buyers of this product are few and picky. This could award you the Nobel Prize, but it could also lead to ruin. A strategy like this demands a lot of capital, cultural as well as economic - it demands a lot of labor of the highest quality. Consequently, not every scientist on the market can do this.

The possible production strategies differ between natural science and medicine on the one hand and the arts and social sciences on the other. It is a conse- quence of different modes of scientific production that are in turn related to the object of investigation. In the arts and social sciences, novelty can more easily be achieved through applying new theoretical perspectives. In these disciplines, theoretical perspectives are often not theorems but frames of interpretation that can be likened to liberal guiding principles. New perspectives have the advantage of bringing out new results from facts that may in themselves be known in advance. This makes it possible to use theory strategically as a tool for competition. New theories come relatively cheaply and may raise the value of the product quite substantially. New theories also make it possible to innovate, and this is not related to market behavior, but is inherent in arts and social science even when we look at them as academic disciplines. However, when the logic of the market kicks in, the rational thing is not to innovate per se, but to compete. This leads to the strategy of applying new theories as a means of (1) creating a unique product, i.e. finding a niche where competition is weaker, or (2) creating novelty, i.e. introducing a fashion and reap the economic benefits from it. This year you may be the only one to sell jackets with velvet collars, but next season there will be plenty of (cheaper) copies.

As previously pointed out by Powell (1991), the market is a mode of interaction that does not build long-term relationships between buyers and sellers, unlike the network mode of interaction. This is because of the role the price plays as a regulator. If the price goes up, the buyer will possibly chose another, cheaper product. Economic action in practice has very little to do with this principle, since organizations have structures (rules, regulations, networks, organization), and companies have a history that means they are enmeshed in a net of resources and relations (Waluszewski \& Håkansson 2007). This is not central to this line of argument, so let us accept the market principles for now. However, there are also other relationships within the market system that are interesting to reflect on, for example the relationships between competitors.

The neoclassical model has very little (or rather nothing) to say regarding relationships; they are simply not important to the model. However, an implication of the model is that competitors compete, i.e. that they do not cooperate, unless somehow it can be assumed that cooperation is rational and can be used as a tool for gaining advantages. The so-called prisoner's dilemma, which is central to rational choice theory, takes as its starting point that solidarity is not rational if one cannot be sure of others exercising the 
same solidarity. In the name of self interest, this is not a likely turnout. If you do not know that other actors will show solidarity, it is more rational to act according to your own self interest. Applying the principle of self interest and the motive of gain on scientists means they do not only compete for (a certain benefit), they also compete against each other (Axelrod 1984).

The economy of modern society is dominated by organizations (e.g. firms, conglomerates, multinationals) and so is science. The scientific community is stratified and specialized. The republic of science is hardly 1 but a number of independent nations, all waving their own flag. Disciplinary and departmental loyalties form the basis for organizational but also cultural boundaries within science (Gieryn 1999). To this we can add a number of other 'trenches' that intersect the landscape: the differences between applied and basic research, between qualitative and quantitative methods, between old and prestigious universities and local colleges, for example. Such dividing lines are numerous, and we have not even begun to discuss the existence of scientific schools. For this discussion, it is not necessary to determine whether it is the department, discipline, school, project group, or some other type of affiliation that functions as 'the company' of the scientist.

The tendency to compete with individuals, schools, disciplines, universities, etc. with whom you are not affiliated will be strong. Another hypothesis is that competition invades the fundamental academic institutions of peer review and the reference system. That is, you do not try to drive your colleagues out of business, but you strategically refrain from writing references to scientific competitors in your articles, as this would increase their capital in a system based on citation indices as measurements of scientific quality. This type of competition may also clash with the traditional competition for discovery, in which acknowledgement of competitors' work is crucial. On the other hand, it might be a good idea to throw in a few footnotes to a scientist with a lot of capital with whom your venture would readily consider some type of collaboration. When such behavior becomes systematic, we can talk about 'citation cartels' or 'citation clubs,' meaning that long-standing social agreements of mutual citation arise (Fuller 2000, p. 86). This behavior is rational in a system based on the market model, even though it may be totally alien to the ideal-typical scientific mind, which cares more about the content and quality of texts than about market relations.

Of course, competition will gradually intensify as the focus on the publication as the sole product of sci- ence becomes more absolute. The market value (and merit value) of a publication will tend to fall if the market is swamped by mediocre products, and as a result of the strategic need to control a publication outlet, journals will increase in number, thus further sharpening the competition for attention (Fuller 2000).

The general conclusion regarding the rationality of the scientist as a producer is that it will tend to downplay discretionary decision making, and shift focus from the text and the result to the publication. This trend weakens scientific norms and disembeds the credibility cycle from the context of discretionary decision making.

\section{THE SCIENTIST AS AN INVESTOR}

Turning to the scientist as an investor, what can be said about the rationality of investment? Scientists can be likened to firms investing in goods and services that will be used in producing new knowledge. These goods can be texts, labor, machinery, and other facilities.

The scientist as a rational investor has to make many choices. As a PhD student, the main capital at hand is labor or time. He/she pays with labor in order to attain certain goods. It will not be rational to invest in goods that are not directly useful in the production of merits. To read books or articles just for the sake of expanding knowledge is not a rational option. It is more rational to read things that can be put to direct use. Rational investor decisions do not favor flippancy regarding how time is used, and unexpected ideas that can result from such excursions are thus less likely to happen. It is also rational to carefully consider the price tag of products in the market. Some products come cheaper in terms of the labor needed to attain them. Some methods are difficult to master, and some research areas demand very extensive reading before even venturing into them. The choice of questions, issues, and perspectives can thus be directly linked to rational investment decisions. In some disciplines, a crucial investment concerns production facilities that demand substantial economic capital. In such disciplines, investment decisions are not made primarily by the individual $\mathrm{PhD}$ student or scientist, but by the project leader.

Climbing the ladder of the academic career, investment decisions thus transform, involving more capital and greater risk, although there are, as has already been mentioned, substantial differences between the natural and social sciences. During mid- 
career, there are questions regarding whether to continue investing in the research field one has started in, or to invest in something new. There are other decisions pertaining to strategies in using time. Should one engage in extensive international networking or stay at home and help run the department? Is a research career a good idea at all or will more teaching give a better return on investment? There are also decisions to be made regarding hiring more labor in the production, i.e. taking on $\mathrm{PhD}$ students or postdoctoral fellows. The meaning of such an act becomes quite different in a marketdominated system than in, for example, Mertonian or Kuhnian science. In sociology of science, no matter which theoretical stance one adopts, the purpose of taking on $\mathrm{PhD}$ students is seen as the reproduction of science, and often of course the reproduction of certain ideas as well as positions. In science as a market, the purpose of taking on PhD students is to increase the competitive edge of the research project. This can be done through increasing labor input so that the project can work faster, and merits can be produced at a higher rate. However, investing in more labor is only rational as long as the labor is spent on the right thing. Seeing science as a market transforms the $\mathrm{PhD}$ thesis from a work aimed both at learning the art and at fixing one's own research interests, into a part of the production machinery. Intellectual development, often meaning shifting interest and starting to develop one's own pet ideas, is not compatible with the goal of competing on the market.

Hiring labor also facilitates another choice, which concerns degree of specialization and division of labor. The academic career demands more than just the ability to do research. Applying for funding, taking part in peer review, and managing universities and other research organizations are all work tasks that are a normal part of the academic career. In principle, the only one of these assignments that can be transferred to a younger (and cheaper) individual is the work involved in research: conducting investigations and experiments and writing texts. The project thus becomes a hierarchy based on the division of work that is most rational according to the goal of competing successfully with other projects. The more market-adapted and industrialized the research project becomes, the more work tasks develop that have nothing to do with research as an activity but with management, marketing, financing, planning, and accounting.

In relation to this industrialized production of science, one of the primary interests of the project leader will be to keep down the labor costs. The most efficient way of doing this will be to ensure that the supply of labor will be greater than the demand, something that will keep the price down. Another method will be to stimulate and maintain the replaceability of the labor, through limiting the body of knowledge held by the labor force (Braverman 1974). Knowledge constitutes the central means of production within the production of science, which is why it is rational to monopolize certain types of knowledge in order to keep down labor costs. In the past century, the standard way of monopolizing knowledge was through mechanization and routinization of work.

The main conclusion regarding the scientist as an investor is that this conceptual transformation tends to alter the character of scientific labor as it becomes a commodity on a market. This will affect learning as well as reproduction of scientific practices and scientific culture. The core of the change regards the nature of the relationships between scientists. The relational character of science ceases to be central at the very moment when scientific labor becomes a commodity and the core transaction becomes a market transaction.

\section{THE SCIENTIST AS A CONSUMER}

First, it is necessary to point out that consumption is one specific action within neoclassical theory, i.e. the act of buying a product or a service. How the product is used is not of interest. Furthermore, it is important to note that consumer preferences are the analytical results of actual (or imagined) deals. Demand is a measurement of the propensity to buy (milk, cars, singing lessons) at a certain price, not a measurement of what is actually desired by the consumer.

The scientist on the market fills the role of consumer in many respects. As an editor, a reader, or an author of a scientific journal, this role becomes very clear, following quite naturally from the fact that the scientific journal really exists on an empirical international market, where the supply of the international publishers of scientific journals is one of the driving forces, and the demand of the academic public the other (Cameron 2005, Gollogly \& Momen 2006, Adler et al. 2008, Taylor et al. 2008). I have briefly touched on the role of the academic as a consumer of texts, which is to demand primarily texts that are in accordance with his research interests and scientific taste. Having in this case to do with an empirical market, we have firm evidence of the limitations of the effect of demand. International publish- 
ing firms work not towards the academic public, but toward research libraries, and they sell their product in a form that hinders the effect of actual demand (Edlin \& Rubinfeld 2004). As an empirical example of a market, it suffers from huge market imperfections, and can possibly be described as an oligopolistic market. A 'consumer rights' movement has accordingly developed in the academic field in the last decade. A good example of how the market logic spurs and forms this consumer movement is www.journalprices.com/, where consumers (as well as producers) can gather information on the cost effectiveness of academic journals, measured as price per citation and decide whether to buy a journal (or publish in it) accordingly. The monopoly situation does not hinder the impact of the demand mechanism in all respects. The use of bibliometrics in order to measure scientific merits rests on the idea that demand constitutes a legitimate measure of quality. If an article is much cited (i.e. it is in demand), it must be of high quality, since it can be shown to have had impact on science in general.

The most centrally positioned consumer within the bibliometric system is the editor of a scientific journal. What he/she consumes is publications offered by individuals. In science as a market, peer review is overruled by demand. The scientific editor has a number of possibilities of affecting what is published in a journal. The bibliometric measure JIF, which affects the status of a journal, will in a market situation be of central interest to an editor. If the journal is run by an international publishing company, it will also be of central (economic) interest to the company. Various strategies in order to improve the JIF have been developed, and these also affect the consumer rationality of the editor. For example, an author/producer does well to write references to material previously published in the journal, as this affects the JIF positively (Taylor et al. 2008, p. 28). It is also more favorable to publish papers by well-known authors that have high scientific status, as market value affects citations in a positive spiral. The editor will demand the work of reviewers who do their work according to his preferences, meaning that they select papers that the readers will be interested in and that will be beneficial to the status of the journal. The reviewers are producers of review reports, and in this case they are not paid for their work, which makes it rational for them to (1) use as little time as possible on the task, and (2) favor work that will in one way or another confirm their own interest and position.

Of course, there is also a hypothetical end consumption of scientific results. They are produced in society, and society (the public or the private sector) often pays for the production. Thus, society is also in many instances the end consumer of science, although society may also be seen as the owner of science. No matter whether society is seen as a consumer or an owner of science, the market model makes it both rational and necessary to take into account what society demands without raising objections. If society wants research on weapon systems, then this is what we do. If society wants research on the climate issue, then this is what should be accomplished. To maintain the right to work on problems that society sees as superfluous or even potentially harmful is not rational.

However, the most problematic aspect of the depicted change regards the difference between consumption and use. The scientist as a consumer is not necessarily also a user, and the market model does not care about use. The scientific use of texts is closely related to reading them. However, reading texts take time, time for which there are alternative uses. The scientist as a consumer needs to consume scientific results, but at the same time wants to consume them rationally, not wasting too much time that could instead be spent on production. Reading thus becomes a task that has to be minimized, and many types of consumer strategies to achieve this will evolve. Reading abstracts only is one such strategy. Reading only articles that are in one's immediate interest, which means that they can quickly be turned into references of one's own, is another. Texts will tend to lose their use value and retain only their exchange value. The main point is that reading becomes instrumental and shallow. Such consumer strategies will tend to form one's reading habits and in the end one's knowledge base and competence for making informed judgments on questions that lie outside one's immediate interest. It will minimize the propensity for genuine critique and expansion of one's own research interests.

Linking the activities of production and consumption together, producer strategies will affect the consumer side in yet another way. Since the increasing competition among producers will tend to expand the number of publications as well as publication outlets, the body of information will become more and more unmanageable through its sheer size. This will also affect reading habits, forcing consumers to concentrate and specialize, thus strengthening the tendency towards specialization already inherent in the logic of production. Consumers will become stratified into many separate consumer segments, for which different producers will cater. 
The main conclusion regarding the scientist as a consumer is that scientific consumerism accentuates the decline of discretionary decision making, but more importantly, it undermines the basis for intersubjectivity. Consumption is disembedded from the context of use and from the norms regarding the use of texts and their value. The knowledge base necessary for intersubjectivity will be diminished.

\section{CONCEPTS THAT RUN AMOK}

Until now I have discussed the scientist in various roles that are related to the idea that science can be conceived as a market, viz. as a producer, an investor, and a consumer. I have placed the supply/ demand mechanism in the center of my argument. The purpose has been to investigate the consequences of introducing market rationality into scientific core activities, like reading, writing, and choosing research questions. Here, I do not concentrate on the potential economic value (in monetary terms) of the result, and how this may affect science, but on how the assumed rationality of the individual in a market system affects science.

I started out the discussion by suggesting a few denominators of scientific rationality, which are as I see it common to the Mertonian and the social constructivist view of science. These were (1) embeddedness of the credibility cycle in scientific norms expressed in discretionary decision making, (2) the relational character of scientific knowledge, and (3) intersubjectivity as a collective producer of trust within the scientific community. I developed this discussion further by demonstrating that economists analyzing scientific rationality have in fact rested safely on a traditional Mertonian and fairly idealistic view of science, often in schizophrenic cohabitation with outright economistic analyses of their rationality. The consequence of such a view is a somewhat confused picture, as the ongoing commercialization and marketization of the university is assumed to leave scientific rationality untouched in a separate sphere. The emanating literature on academic capitalism has started to address the issue but has likewise stopped at the threshold of the laboratory or seminar room. There exist analyses of what happens when economic capital replaces cultural capital as the central capital in the sector of higher education. However, no studies have analyzed what the supply-demand mechanism will accomplish if it is introduced as an alternative to discretionary decision making within scientific core activities like reading, writing, and gathering empirical evidence.
What seems to happen when economic rationality is introduced as a hypothetic driving force is the following:

(1) The supply-demand mechanism will tend to downplay discretionary decision making and shift focus from the text as a means of communicating the result to the text as a commodity on a market of publication. This trend weakens scientific norms and disembeds the credibility cycle from the context of discretionary decision making. Quantity replaces quality as the core of the process of evaluation, as the supply-demand mechanism cannot handle quality. Quality is external to the market model, which proposes itself to be ideologically and morally neutral. Quality is a matter of subjective judgment (individual or collective, i.e. based on cultural values) and can therefore never be neutral. The market model will redefine quality as quantity. Demand as a driving force does not care about what is good or bad science. In fact, is does not even care about what is correct, validated, reasonable, statistically sound, or not. If the market for lies is better than the market for truths, economic rationality says: let us market the lies. Demand's greatest enemy is individual judgment and moral values.

(2) The supply-demand mechanism will tend to alter the character of scientific work as it becomes a commodity on a market. The neoclassical model also leads to a commodification of the scientific result. This concerns the scientific result itself, not only its offspring, the patent. Products are produced for a market. In the neoclassical model of science, only scientific development that leads to a text that can be marketed is desirable, assessable, or even possible to discover. Ideas and thoughts, no matter how brilliant they are, are not marketable. Neither are fruitful alliances, transmittance of ideas, emancipation, or enlightenment. Commoditization will affect learning as well as reproduction of scientific practices and scientific culture. The core of the change concerns the nature of the relationships between scientists. The relational character of science ceases to be central at the very moment when scientific labor becomes a commodity and the core transaction becomes a market transaction.

(3) The supply-demand mechanism will tend to undermine the basis for intersubjectivity. Consumption is disembedded from the context of use and from the norms regarding the use of texts and their value. The knowledge base necessary for intersubjectivity will be diminished. Judgment or discretion is crucial to professional work. In this statement also lies the 
insight that judgment cannot exist without training and substantial knowledge. With no incentives to exercise individual judgment, the knowledge of how this is to be done and how quality is to be assessed according to the collective cultural values of science will slowly disappear.

When Polanyi (1944) wrote his critical work on the industrial revolution, he was able to assess the whole historical process, from the introduction of laissezfaire as a general basis of economic policy, over the erosion of a socially embedded economy, to the reconstruction of social and economic policy. Unlike Polanyi, we are not in the position to do this. We do not know what the exact consequences of the erosion of judgment-driven scientific rationality are or how far it will go. One could set up numerous hypotheses regarding the effects of the downfall of scientific judgment. It has been my aim here to point at a few of them, and to present them in a way as to make the reader reflect on his/her own experiences of the present-day university. Whether there will be a counterreaction and which form it will take remains to be seen.

\section{LITERATURE CITED}

Adler R, Ewing J, Taylor P (2008) Citation statistics. A report from the International Mathematical Union (IMU) in cooperation with the International Council of Industrial and applies Mathematics (ICIAM) and the Institute of Mathematical Statistics. Available at www.mathunion. org/fileadmin/IMU/Report/CitationStatistics.pdf

Arrow K (1962) Economic welfare and the allocation of resources for invention. In: Universities-National Bureau (eds) The rate and direction of inventive activity: economic and social factors. National Bureau of Economic Research, UMI, Princeton University Press, Princeton, NJ, p 609-626

Axelrod R (1984) The evolution of cooperation. Basic Books, New York, NY

Ball SJ (2004) Education for sale! The commodification of everything. King's Annual Education Lecture 2004. Available at http://sys.glotta.ntua.gr/Dialogos/Politics/ CERU-0410-253-OWI.pdf

Braudel F (1982) Civilization and capitalism : 15th-18th century. Vol. 2, The wheels of commerce. William Collins \& Sons, London

Braverman H (1974) Labor and monopoly capital: the degradation of work in the twentieth century. Monthly Review Press, New York, NY

Callon M (1994) Is science a public good? Fifth Mullins lecture, Virginia Polytech Institute, 23 March 1993. Sci Technol Hum Values 19:395-424

Cameron BD (2005) Trends in the usage of ISI bibliometric data: uses, abuses and implications. Libr Acad 5:105-125

Dasgupta P, David PA (1994) Toward a new economic of science. Res Policy 23:487-521

Diamond AM (1988) Science as a rational enterprise. Theory Decis 24:147-167
Diamond AM Jr (1996) The economics of science. Knowl Tech Policy 9:6-49

Douglas M (1986) How institutions think. Syracuse University Press, Syracuse, NY

Edlin AS, Rubinfeld DL (2004) Exclusion or efficient pricing: the 'Big Deal' bundling of academic journals. ABA: Antitrust LJ, 72(1)

Exworthy M, Halford S (1999) Professionals and the new managerialism in the public sector. Open University Press, Buckingham

Fuller S (2000) The governance of science: ideology and the future of the open university. Open University Press, Buckingham

Gieryn TF (1999) Cultural boundaries of science. Credibility on the line. The University of Chicago Press, Chicago, IL

Gollogly L, Momen H (2006) Ethical dilemmas in scientific publication: pitfalls and solutions for editors. Rev Saúde Pública 40:24-29

Greenberg DS (2007) Science for sale. The perils, rewards and delusions of campus capitalism. The University of Chicago Press, Chicago, IL

Hagstrom W (1965) The scientific community. Basic books, New York, NY

Hands W (1996) Caveat emptor: economics and contemporary philosophy of science. Philos Sci 64 (Proc):S107-S116

Hanson R (1995) Could gambling save science? Encouraging an honest consensus. Soc Epistemol 9:3-33

Hawkins K (2001) The uses of discretion. Oxford University Press, Oxford

Hessels L (2008) Conflicting norms in the credibility cycle. Available at www.wtmc.net/wiki/index.php?title= Laurens_Hessesls

Knorr-Cetina KD (1982) Scientific communities or transepistemic arenas of research? A critique of quasi-economic models of science. Soc Stud Sci 12:101-130

Latour B, Woolgar S (1979/1986) Laboratory life. The construction of scientific facts. Princeton University Press, Princeton, NJ

Marglin S (2008) The dismal science. How thinking like an economist undermines community. Harvard University Press, Cambridge, MA

Mauss M (1925/2002) The gift: the form and reason for exchange in archaic societies. Routledge, London

Merton RK (1938/1973) The puritan spur to science. In: Merton RK (comp) The sociology of science. The University of Chicago Press, Chicago, IL, p 228-253

Merton RK (1942/1973) The normative structure of science. In: Merton RK (comp) The sociology of science. The University of Chicago Press, Chicago, IL, p 267-278

Merton RK (1957/1973) Priorities in scientific discovery. In: Merton RK (comp) The sociology of science. The University of Chicago Press, Chicago, IL, p 286-324

Merton RK (comp) (1960/1973) Recognition and excellence: instructive ambiguities. In: Merton RK (comp) The sociology of science. The University of Chicago Press, Chicago, IL, p 419-438

Merton RK (comp) (1968/1973a) Behaviour patterns of scientists. In: Merton RK (comp) The sociology of science. The University of Chicago Press, Chicago, IL, p 325-342

Merton RK (comp) (1968/1973b) The Matthew Effect in science. In: Merton RK (comp) The sociology of science. The University of Chicago Press, Chicago, IL, p 439-459

Merton RK (1935/1970) Science, technology and society in seventeenth-century England. Harper \& Row, New York, NY 
Michael M, Wainwright S, Williams C, Farsides B, Cribb A (2007) From core set to assemblage: on the dynamics of exclusion and inclusion in the failure to derive beta cells from embryonic stem cells. Sci Stud 20:5-25

Mirowski P (2009) Why there is (as yet) no such thing as an economics of knowledge. In: Kincaid H, Ross D (eds) The Oxford handbook of philosophy of economics. Oxford University Press, Oxford, p 99-156

Mirowski P (2011) Science mart. Privatizing American science. Harvard University Press, Cambridge, MA

Mirowski P, Sent EM (2008) The commercialisation of science and the response of STS. In: Hackett EJ, Amsterdamska O, Lynch M, Wajcman J (eds) The handbook of science and technology studies, 3rd edn. MIT Press, Cambridge, MA, p 635-690

North D (1990) Institutions, institutional change, and economic performance. Cambridge University Press, Cambridge

Polanyi K (1944/2001) The great transformation: the political and economic origins of our time. Beacon Press, Boston, MA

Powell WW (1991) Neither market nor hierarchy. Network forms of organization. In: Thompson G, Frances J, Levacic R, Mitchell JC (eds) Markets, hierarchies and networks. The coordination of social life. Sage Publications, London, p 265-276

Rombach B (1997) Den marknadslika kommunen. Nerenius \& Santérus, Stockholm

Editorial responsibility: Susan Mooney,

Easton, Massachusetts, USA
Rombach B (2005) Den framgångsrika ekonomiskan. Santérus förlag, Stockholm

Sennett R (2008) The craftsman. Yale University Press, New Haven, CT

Shapin S (2009) The scientific life. A moral history of a late modern vocation. The Chicago University Press, Chicago, IL

Slaughter S, Leslie LL (1997) Academic capitalism. Politics, policies, and the entrepreneurial university. The Johns Hopkins University Press, Baltimore, MD

Slaughter S, Rhoades G (2004) Academic capitalism and the new economy. Markets, state and higher education. The Johns Hopkins University Press, Baltimore, MD

Stephan PE (1996) The economics of science. J Econ Lit 34: 1199-1235

Stephan PE, Everhart SS (1998) The changing rewards to science: the case of biotechnology. Small Bus Econ 10: 141-151

Taylor M, Perakakis P, Trachana V (2008) The siege of science. Ethics Sci Environ Polit 8:17-40

Waluszewski A, Håkansson H (2007) Knowledge and innovation in business and industry. The importance of using others. Routledge, London

Weber M (1904-1905/2001) The Protestant ethic and the spirit of capitalism. Routledge, London

Ziman J (2000) Real science. What it is and what it means. Cambridge University Press, Cambridge

Submitted: January, 14, 2011; Accepted: September 14, 2011 Proofs received from author(s): January 20, 2012 